\title{
Two Images of Russia in the British Political Mass Media Discourse of 1991 - 1993 and 2013 - 2019: Pragmastylistic Aspect
}

\author{
Natalya B. Boeva-Omelechko \\ Department Institute of Philology, Journalism and Cross-cultural Communication, Southern \\ Federal University, Rostov-on-Don, RUSSIA \\ (D) 0000-0002-6992-635X SC 57205247954 A-3412-2017
}

Ksenia P. Posternyak

Department Institute of Philology, Journalism and Cross-cultural Communication, Southern Federal University, Rostov-on-Don, RUSSIA

(iD) 0000-0002-5227-878X F-9049-2018

Marina R. Zheltukhina

Institute of Foreign Languages, Volgograd State Socio-Pedagogical University, Volgograd, RUSSIA (D) 0000-0001-7680-4003 SC 56669701900 A-7301-2015

zzmr@mail.ru

\section{Elena B. Ponomarenko}

Faculty of Philology, Peoples' Friendship University of Russia (RUDN University), Moscow, RUSSIA

(D) 0000-0003-3181-507X SC 57191415307 A-7301-2015

\section{Elena V. Talybina}

Faculty of Philology, Peoples' Friendship University of Russia (RUDN University), Moscow, RUSSIA

(DD 0000-0002-0062-349X SC 57200450847 D- $7509-2019$

\section{Alexander K. Kalliopin}

Institute of Foreign Languages, Moscow Aviation Institute, Moscow, RUSSIA

(i) 0000-0002-5882-3996

\section{Maria N. Ovsyannikova}

Institute of Foreign Languages, Moscow Aviation Institute, Moscow, RUSSIA

(D) 0000-0003-3928-113X

\author{
ARTICLE INFO \\ Received: 12 August 2019 \\ Accepted: 21 September 2019 \\ Published: 7 October 2019 \\ DOI: https://doi.org/10.29333/ojcmt/5952 \\ ABSTRACT \\ The paper considers political mass media discourse as a persuasive dialogue in which a \\ journalist makes his interlocutors accept a certain point of view. The desired mental \\ reaction on the part of interlocutors can only be achieved through careful choice of ways \\ of persuasion and especially linguistic means often influencing effectively the emotional \\ sphere. The persuasion can be subject to ideological aims thus representing a definite \\ object as positive or negative. The paper claims that such object as the image of state can \\ have opposite assessment in different periods of time and focuses on linguistic means of
}


persuasion aimed at the creation of two contrasting images of Russia in the British mass media discourse of $1991-1993$ and $2013-2019$.

Keywords: dialogue, political mass media discourse, positive persuasion, negative persuasion, image of state, contrast, linguistic means

\section{INTRODUCTION}

Nowadays pragmatic linguistics still occupies an important place among the priority paradigms of the XXI century (Leech, 1983; Levinson, 1983; Thomas, 1995, etc.). It considers language as a tool of speech influences. The latter are treated as purposeful effects causing a certain reaction of interlocutors.

These effects include, first and foremost, different expressions of will, including persuasion, i.e. the act of persuading in the course of which a subject of persuasion "... influences, moves or prevails on by argument, advice or expostulation to a certain belief or course of action" (Finnegan, 1989).

Persuasive function is most fully implemented in persuasive discourses, which are defined by Lakoff (1982) as non-reciprocal discourses whose primary aim is to persuade listeners or readers to change their behavior, feelings, intentions or opinions by communicative means, either linguistic or non-linguistic.

Persuasive texts, representing such discourses, seek to influence the mental sphere of the recipient (his / her opinion, assessment) in order to change his / her behavior (inducement to commit / refuse to commit certain actions).

It goes without saying that one of the most persuasive discourses is mass media discourse, and especially political one, because "it's difficult to overvalue the role of mass media discourse in creating and changing individual worldview" (Posternyak \& BoevaOmelechko, 2018). van Dijk (1989) believes that “...of all forms of printed texts, those of mass media are the most persuasive, if not most influential, when judged by the power criteria of recipient scope" (van Dijk, 1989).

These texts being monologic are at the same time inherently dialogic because, first, dialogue interaction is not restricted to turn-taking (Weigand, 2010) and, second, persuasion is impossible without the object of persuasion (a reader), though a sender of the message and its recipient are not equal in rank: the former dominates the latter as it's typical of persuasive discourse in general (Lakoff, 1982).

But an interlocutor is of primary importance for a subject of persuasion (a journalist) because he must find effective ways of making him accept this or that point of view and see events at a certain angle. It is a reader whose beliefs and stereotypes a journalist shapes and changes in the process of persuasive communication and it who "mentally acts" (van Dijk, 1995), accepting or rejecting the journalists' point of view.

Ways of persuasion, in our opinion, include both factual information (the content of a journalist's message), which can be true or false, exaggerated or understated, i.e., which influences primarily the rational sphere of the recipient, and linguistic means (the form of the message), which often can be aimed at his irrational, emotional sphere and thus raise the effectiveness of persuasion.

The choice of linguistic means in question can be subject to ideological tasks thus representing a definite object or phenomenon as positive or negative. It is worth mentioning that one and the same object can have opposite assessment in different periods of time. So the aims of persuasion and linguistic means necessary for them will be also different. 
It is especially true in relation to images of states which undergo transformations in one and the same discourse due to changes in international relations. According to $\mathrm{K}$. Boulding (1956), "we have on the one hand the 'postwar' periods in which, on the whole, things go from worse to better, and we have the 'prewar' periods in which things go from better to worse". So in the first case journalists have to convince the recipients of their persuasive messages that a certain state is friendly or at least not dangerous and in the second case to depict it as an enemy. It is quite clear that the presupposed reaction of readers as participants of this dialogue and objects of the persuasion will be quite different. Speaking about reaction, we mean in this case the readers' attitude to the state in question and to the foreign policy of their own state towards this state.

In this paper, we shall focus on such changes of goals of persuasion and linguistic means of their implementation in British mass media discourse of 1991 - 1993 and 2013 - 2019. In these two periods, two contrasting images of Russia as a friendly newly born state free from communist ideology and, on the contrary, a dangerous, aggressive enemy have been created in this discourse. Analysis of corresponding persuasive messages will contribute to the further study of the problem 'dialogue in the stream of life' (Weigand, 2015) and the persuasive possibilities of political mass media.

\section{LITERATURE REVIEW}

The recognition of the active role of interlocutor in pragmalinguistics (Bierwisch, 1971; Gumperz, 1982) gave the opportunity to make a shift from a monologic speech act theory (Austin, 1962; Searle, 1969, 1983) to a dialogic one. Since then, the focus of scientists has been interaction, i.e. the exchange of actions (both verbal and non-verbal), which involves at least two people (Boeva 2001).

This shift is noted in works by Hundsnurscher (1992) and Weigand (see, for instance, $2010,2017,2018$ ) dealing with a problem of dialogic character of natural language use.

The theory of the concept of 'language as dialogue', created by Weigand (2009, 2010, 2016, 2018), provides us with the necessary theoretical assumptions for considering political mass media discourse as a rhetorical argumentative dialogue in the course of which a journalist convinces readers in a certain point of view, eliciting a particular reaction from them.

Of course, not verbal but mental reactions and practical actions are reactions typical of interlocutors in mass media discourse. These reactions depend a great deal on aims and effectiveness of persuasive messages created by journalists.

Speaking about persuasion in political mass media discourse, we should stress that the term 'persuasion' (from Latin persuasia) comes from rhetoric - “... the art which teaches persuasive oratory" (Finnegan, 1989). Rhetoric originated in the ancient period of human development and from the very beginning, its focus was on the methods and rules of persuasive speech, which in modern science are called communication technologies.

As Crystal (2008) notes, "the study of rhetoric has been given a new lease in modern course on communication, where the aim is to understand the process underlying successful argument and persuasion”. According to German scientist Koppersmith (1973), we can talk about persuasive rhetoric as a methodology of persuasion in the sphere of humanitarian knowledge.

The revival of interest to the problems of dialogue, argument and persuasion began in the 60 s of the twentieth century and is connected with works of Chaim Perelman, a 
N. B. Boeva-Omelechko, et al.

Belgian lawyer, who introduced the term "New Rhetoric" (Perelman, 1979; Perelman \& Olbrechts-Tyteca, 1969) which soon gained popularity.

The broad interpretation of the subject of rhetoric suggests that language and speech perform the function of persuasion and intention in public practice. It is worth mentioning that persuasion is treated in Perelman's work as a process of interaction between a subject of persuasion and audience. The latter is treated as an imaginary group of people that a speaker or writer wants to influence through the use of argumentation (Perelman \& Olbrechts-Tyteca, 1969). He usually constructs a model of the audience, appropriate for a certain situation. Thus, audience is recognized as an active participant in the process of communication and especially persuasion. This confirms the point of view of the dialogic character of the process of persuasion in the media discourse.

One of the aim of this persuasion is the creation of images of states. Boulding (1959) introduced the concept 'image of state' (1956). According to him, the image of state includes cognitive, emotional and evaluative constituents, which we will consider in our further research.

The inherent characteristics of the image of state are its dynamic character and dependence on international relations (Boulding, 1956). Feeling itself insecure, the nation creates the image of the aggressive state threatening it, which leads to arms races (Minakova, Ponomarenko, \& Talibina, 2018; Repina et al., 2018; Tameryan et al., 2018a, 2018b, 2019; Volskaya et al., 2018; Zheltukhina et al., 2016a, 2016b, 2019). If the situation improves, the image of the rival can be replaced by the image of the partner. Then the situation can change to worse again and the image of the hostile state will dominate.

Argumentative dialogue especially in political mass media discourse is characterized by a dichotomy of rational and emotional impact (Brinker, 1997). In the effort to convince the audience in their negative or positive assessment of the state, i.e. to have the desirable mental reaction from it, journalists have to use both rational (factual) arguments, aimed at rational persuasion of the recipients, and emotional or value arguments evoking positive or negative emotions of the audience and thus forming a desirable attitude to the state. The combination of rational and emotional arguments leads to the formation of the image of state, including its cognitive, affective and evaluative constituents (Privalova et al., 2019; Repina et al., 2018; Zheltukhina et al., 2017, 2018).

Leaving aside factual arguments, which are beside interests of linguistics, we shall focus on affective and evaluative ones, which are realized with the help of different linguistics means chosen by journalists in their dialogue with the audience. To do this, we will consider the mechanisms of creating a positive image of Russia in the British political mass media discourse of the end of the twentieth century, when New Russia was born after the split of the Soviet Union, and a negative image of aggressive New Russia, created in the last seven years.

\section{METHODOLOGY}

The objective of this study is to reveal and compare linguistic means used by British journalists for positively oriented persuasion (creation of the positive image of Russia in 1991 - 1993) and negatively oriented persuasion (creation of the negative image of Russia in 2013 - 2019) and analyze their effectiveness in creation of two contrasting images of one and the same state.

First, a small-scale corpus of about 1500 micro contexts, comprising the lexeme 'Russia' and its substitutes, was constructed. 664 micro contexts refer to 1991-1993 and 836 to 
2013-2019. These micro contexts were extracted from the websites of the British newspapers The Times, The Guardian, The Observer, The Financial Times, The Morning Star, The Daily Telegraph, The Daily Mail, the journal Economist, the electronical journals and newspapers The Standpoint, The Opendemocracy, The Spectator and websites bbc.uk, theconversation.com, calvertjournal.com, chathamhouse.org, blogs.reuters.com, medium.com, newsthump.com, prospectmagazine.co.uk, spikedonline.com, newstatesman.com, gov.uk, standpointmag.co.uk, blog.oup.com, theduran.com, bne.eu.

Speaking about micro contexts of 1991 - 1993 we should mention that most of them (61, 14 per cent, i.e. 406 examples from the total number of 664) were found in the newspapers of 1991. This is quite understandable as at the end of 1991, the collapse of the Soviet Union was legally formalized, which led to the change of power and, moreover, the change of the socialist system to the capitalist one. This was the goal that the West has long sought, and the achievement of which the Western press has assessed as a victory over Russia. The euphoria of the victory over the Soviet Union somewhat subsided by 1993. By this time the flow of articles devoted to Russia has decreased.

Today we see the opposite trend: the concept 'Russia' is again in the center of the journalists' attention. The interest to Russia in Britain is great again because of the reunification of Crimea with Russia, the conflict in the South-West of Ukraine, Russian military help to Syria, doping scandals, the International Football Championship and others.

As for the present period, a leading role in the formation of the image of Russia in Britain belongs to The Guardian (245 micro contexts) and The Financial Times (98 micro contexts). The listed websites were also of great use for our research. We would like to note that many magazines and newspapers do not have printed versions and are published only in the network.

The language means of realizing the strategies in question in the British political media discourse in two compared periods were revealed and interpreted with the methods of contextual, pragmalinguistic, critical discourse and stylistic analysis, described in works by Firth (1957), Harris (1952), van Dijk (1981, 1993, 1995). The contextual analysis gave the opportunity to make a list of lexemes and word groups, used for the nomination of Russia, as well as the list of evaluative lexemes and other lexemes purposefully used together with the nominations of this state in the same micro contexts for forming associations necessary for the persuasion.

Pragmalinguistic and critical discourse analyses, including socio-political and moral factors into a given research agenda (Parker, 1999), reveal the journalists' intentions, which determine the choice of linguistic means and which, in their turn, depend on some ideological background.

Stylistic analysis, dealing with expressive means of the language with their great persuasive capacity, was aimed at the investigation of such means and especially metaphors, helping to create the image of Russia in the British mass media discourse. The metaphors were revealed with the help of Conceptual Metaphor Analysis (CMA) (Lakoff \& Johnsen, 2003), presupposing the comparison of the contextual meaning of the word or word group in the text with the basic meaning in the system of the language. In the case of their contrast the lexical meaning is marked as figurative or metaphorical (Pragglejaz Group, 2007). 
N. B. Boeva-Omelechko, et al.

At the final stage of investigation, the comparative method was used, i. e. the method "which the primary concern is to make statements comparing the characteristics of different languages (dialects, varieties, etc.)" (Crystal, 2008). Language means used by British journalists for positive and negative persuasion (i.e. for creating positive and negative images of Russia' in 1991 - 1993 and 2013 - 2019) were compared, which gave the opportunity to show the difference between two images of Russia imposed on the British audience during the periods under the review.

The texts on the topic under study were extracted from the websites, classified and compared in accordance with the approach described above, i.e. as means, helping to create affective and evaluative constituents of the image of Russia.

Then they were interpreted with the help of the above-mentioned methods for revealing their role in positive and negative persuasion oriented towards creation of positive and negative images of Russia.

\section{RESULTS AND DISCUSSION}

90-s of the previous century faced the collapse of the Soviet Union, the ideological rival of capitalist states, and the birth of New Russia, presumably less dangerous for Great Britain. In terms of Boulding (1959), it was a postwar one, when things changed from worse to better for western states, as they were winners in the ideological war over the dangerous superpower. As May (2018) says nowadays

(1) Britain looked at a post-Soviet Russia with hope (May, 2018).

At this period British journalists combined the positive persuasion, aimed at the creation of the positive image of New Russia trying (2) to get out of the red (Binton, 1992) with the help of the City, with the negative one, oriented towards the full and final discreditation of the Soviet Union.

Realizing the latter strategy, British journalists represented the death of the Soviet Union as a joyful event favorable not only for the enemies of the superpower but for Russians as well:

(3) The evil empire whose break-up we should applaud (Millinship, 1991a).

(4) New Russian feeling that they were the victims of their own empire (Frankland, 1991b).

(5) The majority see a simple choice - back to the bad old days or a swift jump to democracy (Hastings, 1991c).

The journalists emphasized that for Russian people the collapse of the Soviet Union was (6) the reward for decades of tyranny and mismanagement (Ponsett, 1991).

The nomination Evil Empire and different evaluative adjectives, depicting the Soviet Union as a tyrannical, cruel, unfriendly and ineffective system, hated by everybody, were effective tools of the negative persuasion:

(7) The Union of Soviet Socialist Republics, one of the 20th century's the most cruel and inept creations, is today not killed (Jenkins, 1991).

(8) The west has nothing to gain from helping the Communists hold captive nations inside a seedy, brutal, bankrupt and hated system (Weaver, 1991).

(9) Nigel once described the Soviet players as 'warped, twisted and mean'. Coming from what has been an unfriendly and unpleasant system they have this meanness. (Lawson, 1992). 
(10) They have to be tough to survive (Lawson, 1992).

Realizing the negative persuasion, British journalists also created micro contexts in which the name of the Soviet Union was used together with such nouns as tyranny, oppression, autocracy, thus forming strong associations between the Soviet Union and all these negative concepts. For example:

(11) The isolation, on which Soviet tyranny always depended, could not be reestablished (Davies, 1991).

It helped to convince the readers that Soviet Union is the antipode of democracy:

(12) [...] democracy and the Soviet Union are not compatible (Hastings, 1991b).

(13) Gorbachev didn't understand the contradiction between democracy and the Soviet state (Hastings, 1991b).

The examples above show that British journalists used contextual antonyms Soviet Union (State) - democracy both in titles and in the body of the articles thus forming associations based on contrast in the minds of interlocutors.

British journalists did the utmost to make their interlocutors think that democracy was alien to the Soviet Union because of the communist regime based on the oppression. The death of the Evil Empire meant the victory over communism:

(14) The Soviet Union being the creation of communist power and communist ideas, cannot survive the defeat of the communism (Davies, 1991).

Convincing readers that the death of the USSR was natural, because its creation was an unsuccessful and destructive experiment, British journalist used oxymoronic utterances in which rich natural resources of the USSR and the military capacity of the nuclear superpower were opposed to the poverty of the Soviet Union resulted from the ineffective system and management:

(15) Here was a rich country which had squandered its human and material resources and ran its economy so badly that it was almost bankrupt (Fishlock, 1991).

(16) A rich country made poor by its rulers (Bayers, 1992).

One of the journalists went further and compared the Soviet Union with a white elephant (useless property that is burdensome to keep and difficult to get rid of), using the appropriate idiom, which helped to create a vivid and memorable image:

(17) One of the less grandiose, but more ridiculous, white elephant was being dismantled yesterday... (Warren, 1991).

The death of the USSR, inextricably linked with the appearance of a new country, was often described in the British media discourse through morbial metaphors. For example:

(18) The Soviet Union died with a whimper around 5pm on Thursday under the brilliant circular crystal ceiling light of the USSR parliament chamber in the Kremlin (Millinship, 1991b).

Such metaphors, representing the Soviet Union as a dead body, were also necessary to convince the readers that the Evil Empire has gone forever and can't be restored.

Not denying the death of the communist state, some journalist continued to realize the negative persuasion depicting Russia as a successor of the USSR with all its faults and problems. It was the persuasion by inertia calling into question the possibility of building a state of a new type on the ruins of the old communist empire. 
N. B. Boeva-Omelechko, et al.

First of all, lexeme was used in the British political mass media discourse such as 'former Soviet Union', 'Russian-Soviet state', 'Russian Empire' showing the inseparable connection between Russia and the Soviet Union.

Secondly, referring to history of Russia, they expressed doubt about the possibility of democracy and law observing in this country:

(19) The rule of law has never been Russia's strongest suit, whether under the tsars or the communists (Traynor, 1993).

(20) In spite of dismantling of the totalitarian system, Russia remains a long way from the 'law based' state which perestroika tried to build (Till, 1992).

The following emotional rhetorical question, addressed to the interlocutors, reinforced the factual arguments:

(21) Is tyranny rooted in Russian psyche? (McElvoy, 1993).

Finally, the journalists depicted Russia as a country not less dangerous than the Soviet Union, forming associations of Russia with nuclear weapons and militarism:

(22) Russia likely to become new nuclear superpower (While, 1991).

(23) The Soviet nuclear superpower is well on its way to transforming itself into the Russian nuclear superpower, western experts believe (While, 1991).

For emotional persuasion a zoomorphic metaphor, comparing Russia with a dangerous elephant capable of smoothing its neighbors, and constructional metaphors, depicting Russia as a dangerous ruin, were used:

(24) We must realize that we are realize that we are sharing a bed with an elephant (Russia); if it rolls over it can smooth us (Lloyd \& Freeland, 1993).

(25) A dangerous ruin (Hastings, 1991a).

But on the whole such statements were not prevailing in 1991 - 1993 and there was nothing new in them. They only duplicated or complemented the image of the Soviet Union.

Inside the negative persuasion it's also possible to single out another trend, which aim was not to discredit the Soviet Union and Russia as its successor but to oppose the weakness of the latter to the greatness of the former Empire. It was the triumph of the winner over the defeated enemy. This line of persuasion was realized through evaluative adjectives depicting Russia as humiliated, tired, angry, uncertain and extremely poor country. For example:

(26) What is he (Yeltsin) doing with this tired, angry country? (Frankland, 1992b)

(27) Russia woke up confused and uncertain (Preston, 1992).

British journalists effectively used construction and artifact metaphors convincing readers of the catastrophic economic situation in Russia:

(28) Now Russia represents itself the smoking ruins of an old empire (Preston, 1993b).

(29) The country is bloody deep in ruins. It has got to be put together piece by piece (Bolton, 1991).

(30) Most of the furniture in the Russian house is outmoded and inconvenient, but there is no money to buy new ... (Frankland, 1992a).

(31) Yeltsin is like the inheritor of a great but crumbling estate, with the ambition, but not yet the means, to restore its former splendor (Frankland, 1992a).

The idea of poverty was also rendered with a gamble metaphor: 
(32) The former USSR is rushing towards a gigantic economic and social gamble, in which millions will be instantly impoverished (Millinship, 1991b).

The hidden ideology underlying the negative persuasion in question can be disclosed with the following statement, opposing the pride typical of once great nation to its present humiliating situation:

(33) For a proud people used to thinking of their country as a successful superpower, it must be a shocking humiliation to have failed so far (Hastings, 1992).

However, for most journalists of that period the negative image of the Soviet Union (Russia) gave the opportunity to represent an optimistic contrasting image of New Russia born after the collapse of the Evil Empire. They convinced their readers that New Russia is a democratic state with a great potential for development:

(34) Flush with his victory at the Russian elections Mr Boris Yeltsin flies to Washington this week as the first democratically elected leader of a great country with huge resources and a long history (Lambert, 1991).

So British journalists used contrast as another effective way of persuasion, this time a positive one.

In this connection, we should mention several antonymic oppositions which helped to implement the positive persuasion in question (Boeva-Omelechko et al., 2018; BoevaOmelechko, 2001). The negative members of these oppositions were used in contexts, dealing with the Soviet Union, while the positive ones contributed to the creation of the new state.

The first of these oppositions is the opposition old-new used for nominating the Soviet Union and post-Soviet Russia. The former was called the old-style Soviet state or the old Soviet state whereas the latter was nominated with the word group, including the adjective new (new Russia). For example:

(35) Mr. Yeltsin and the other republican leaders ... are less interested in pursuing the great power ambitions that bankrupted the old-style Soviet state over which Mr. Gorbachev still presides (Lambert, 1991).

(36) He faces the longer, less controllable test of bringing together, constructing and letting grow new - and opposing - forces which will form a new Russia (Lloyd, 1993a).

The nomination New Russia was reinforced by the contextually evaluative adjective modern used in relation to Russian people in combination with the adjective sophisticated, also positively characterizing them as people having a new way of thinking:

(37) By and large the Russians have shown themselves to be modern, sophisticated people (Hastings, 1992).

As part of the juxtaposition of the old and the new states British journalists also opposed Gorbachev as a Soviet leader of an old type who, in their opinion, was too slow in dismantling the rotten system, and Yeltsin, who was much more successful on this way and was depicted as a leader of a new type. The failure of the first one and the success of the other were emphasized with the antonymic opposition weakened - strengthened:

(38) What have they left behind? A greatly strengthened Russian president and a gravely weakened Soviet one: precisely the opposite effect to that they intended (Lloyd, 1991).

The second opposition is the opposition death (dead, die) - birth (be born), the members which described correspondingly the collapse of the Soviet Union, as it was shown above, and the appearance of a new state. For example: 
N. B. Boeva-Omelechko, et al.

(39) A superpower dies and 'a great dream' (Russia) is born with treaty (Dejevsky, 1991).

The next oppositions tyranny (oppression) - freedom, autocracy - democracy gave the opportunity to create the image of a new state which won the victory over Soviet tyranny and which was to become a democratic state. For example:

(40) Russia offers us the unprecedented spectacle of an imperial power extricating itself from its empire in order to gain freedom for itself (Pipes, 1991).

British journalists convinced readers that on its way to democracy Russia will become a better state in all respects:

(41) We held out the hope not just of democracy but of a more honest, fairer Russia, freed of official privilege and corruption (Stothard, 1993).

Some journalists used anthropomorphic metaphors comparing Russia with a person awakening from the Communist dream and straightening its muscles. It helped to convince the readers that Russia had finally understood its misconceptions and was gaining strength:

(42) Russia now stretching and flexing its muscles, as if after a long sleep (Lloyd, 1993b).

(43) After a long sleep, Russia awakes (Lloyd, 1993b).

Russia was also represented as a lady taking off the dress of communist ideology:

(44) The Russian empire is taking its red Soviet dress off (Frankland, 1991a).

The oppositions poor - prosperous and unfriendly - friendly (friendship) were necessary to oppose the poverty and unfriendliness of the Soviet Union and its isolation from the whole world to prosperous New Russia as a potential friend of the West and Britain in particular which helped to make the latter image even more attractive:

(45) Boris Eltsin was called (45) the elected president of what is now supposedly a friendly country' (Preston, 1993a).

(46) In response, the west must continue ... working for the greater prize; a stable and prosperous Russia anchored by ties of permanent friendship to the west (Preston, 1993c).

Nowadays the situation has changed dramatically. British political leaders view Russia again as the threat to the security of their country in the light of such events such as the reunification of Crimea with Russia, the conflict in the South-West of Ukraine, Russia's military help to Syria doping scandals. In accord with it the positive persuasion in the British mass media discourse turned into negative again. It is aimed at the creation of quite a different image of Russia, an image of an aggressive, unpredictable and extremely dangerous state, hell-bent on grabbing lands.

As one of the journalists states:

(47) Russophobia-or the unnatural fear of Russia-generally leads magazine editors to choose the most over-the-top images to convey Russia as a backwards, clumsy, nonWestern and aggressively malevolent power (Basulto, 2016).

Such a negative image supports the standpoint of British today's Prime Minister Theresa May (2018), who characterizes Russia as a hostile state and says that

(48) "Britain will urgently develop proposals for new legislative powers to harden [...] defenses against all forms of Hostile State activity" (May, 2018). 
For purposes of negative persuasion British journalists again use the technique of manipulating nominations. Thus, thanks to T. May (2018), Russia became known in the British political media discourse as 'the Russian state'. For example:

(49) Perhaps the only thing more satisfying than the World Cup's success has been Mr Trump's tour of Europe: underlying Nato, rattling governments and humiliating the leader of a close ally which is still dealing with the aftermath of a fatal nerve agent attack blamed on the Russian state (Viner, 2018).

This word group is very convenient for the persuasion as it can be easily transformed into an above-mentioned evaluative nomination Hostile state.

No less popular is the nomination President (Vladimir) Putin's Russia' or even tzar Putin's Russia. For example:

(50) How dangerous is Vladimir Putin's Russia? (The FT, 2018).

(51) Without America, Britain must lead in standing up to Tsar Putin's new imperial Russia (Hastings, 2017).

It is worth mentioning that nominations of Russia have never included personal nouns in a possessive case before (Tzar Russia, Great Russia, Soviet Russia, Mother Russia) and new nominations are designed to show the world that all power in Russia is concentrated in the hands of one dictator.

No wonder that the new nomination was complemented with the artifact metaphor serving the aims of negative persuasion: the metaphor comparing Russia with outmoded and inconvenient house in 90s transformed in the modern British media discourse into Putin's house, which he personally built and is not going to give to anyone:

(52) Russia is the house that Vladimir Putin built - and he'll never abandon it (Trenin, 2017).

Alongside with the new extremely negative evaluative nominations British journalist use the already known word group New Russia giving it a new meaning. This nomination has lost its positive connotations and is used to show that Russia gained strength and became 'new' in relation to the 90s. This New Russia is a political rival of Great Britain and other countries. For example:

(53) New Russia acts in deliberate, intransigent opposition to US (Tisdall, 2014).

(54) The broader 'New Russia' plan... (Mujanović, 2014).

Recognizing the important role of this New Russia in the world today, British mass sometimes publish articles, expressing approval of Russia's desire to stand up America on its way to the world leadership. For example, in the Guardian we come across the interview with Neli Esipova, Gallup's regional research director for eastern Europe and the former Soviet Union, who summed up the results of the recent Gallup poll measuring opinion in 133 countries and areas and said:

(55) Even if people don't approve of Putin, there is some admiration of Russia admiration maybe a strong word - but many people have gained respect for Russia for the fact that they try to stand up against the US and the west (Durkin, 2019).

Some journalists try to convince their readers that Russia is not an enemy and the cooperation of two countries is mutually beneficial. For example:

(56) Like it or not, Russia and the UK need each other - and will have to talk (Kortunov, Chalmers, 2018). 
N. B. Boeva-Omelechko, et al.

But such publications are very few. The general line of contrasting negative persuasion is reflected in the following statement:

(57) Our motto with Russia must be to 'engage but beware' and both halves of the formula should be pursued with equal resolve (Johnson, 2018).

Creating the image of a hostile state, British journalists today attract their readers' attention mainly not to inner problems of Russia as it was in 1991 - 1993 but to its foreign policy. Articles devoted to inner problems of Russia focus on its weak economy that has suffered from sanctions and on the poverty of Russian people. For example:

(58) The cumulative result of all these mis-steps is that Russia is much poorer and more isolated than it should be. Its economy is under sanctions and the years of rapid growth before 2008 are a receding memory (Rachman, 2018).

(59) Vladimir Putin's military adventurism and rampant cronyism stifled the potential of that vast country, and sanctions pushed it to the brink of financial collapse (Lynn, 2019).

To make the persuasion more effective, British journalists oppose the splendor and success of the World Cup in Russia to the grim reality of everyday life in this country:

(60) This summer, the World Cup created the illusion Russia was a well-run country with a contented population. But now the sports pageantry is over, Russians are back to the grey reality of everyday life, and a dire lack of prospects (Mendras, 2018).

A naval metaphor comparing Russia with a creaking ship can also be regarded as an effective way of the negative persuasion in question:

(61) Vladimir Putin's Russia is a creaking ship. Don't fall for the propaganda (Mendras, 2018).

The description of the economic difficulties in Russia gives British journalists the opportunity to use the contrast between Russia's poverty on one hand, and its great military capacity and geopolitical ambitions, on the other. Thus they convince their interlocutors that militarism is the only strong point of Russia:

(62) What we are seeing is a Russian return that is trying to find a niche where they can be competitive. The niche they really own is arms (Beaumont, 2018).

Nouns with negative connotations, combining in their meaning the correlation to the referent and evaluation thus realizing the technique of manipulating nominations, also contribute to the negative persuasion and help to represent Russia as an enemy. For example:

(63) Russia is once again the west's primary adversary (June, 2016).

(64) But Russia has chosen to become a strategic competitor of the West (Fallon, 2017).

(65) Russia has shown itself to be a strategic enemy, not a strategic partner," said one senior British official. "The Russian threat does not respect borders and we are all at risk" (Rachman, 2018).

The evaluative nouns used for the purposes of persuasion can name and give characteristics not only to the state but to its actions which helps to enhance the effect on interlocutors' feelings.

Thus, the annexation of the Crimean Peninsula to Russia is represented in the Englishlanguage political media discourse as a manifestation of Russian aggression and is described with such words as intervention, invasion, assault, merger and grab. For example: 
(66) Russia's land grab in Crimea amounted to the first forcible annexation of the territory of a European country - and the first forcible redrawing of a European frontier - since 1945 (Johnson, 2018).

The words intervention and intervene are also used for the description of Russia's military operation in Syria. British journalists successfully convince their readers that the operation is aimed at supporting the cruel dictator Bashar al-Assad:

(67) The hope must be that criminal justice will one day close in on Syria's murderous dictator Bashar al-Assad, his henchmen and his enablers ... It's true that geopolitics have gone Assad's way since Russia and Iran intervened forcefully to prop him up (Nougayrède, 2019).

The actions of the Russian authorities to resolve the conflict in Ukraine British journalists nominate with the verb violate. Moreover, representatives of the republics proclaimed in Donbass are referred to as Russia-backed separatists (Russian-backed separatist, pro-Russian separatist, pro-Russian rebels), which emphasizes the desire of these people to split the country as well as their support from Russia. For example:

(68) And I remember the city of Donetsk: renovated before the Euro 2012 football championships, it resembled many other globalized eastern European cities, with both a McDonald's and a Lenin monument in its main square. Now it's occupied by pro-Russia separatists and has been turned into a military dictatorship (Kariakina, 2019).

It goes without saying that evaluative adjectives with negative connotations are used by British journalists for depicting modern Russia as an evil state (aggressive, ambitious, authoritarian, dangerous, rotten etc.). For example:

(69) The doping scandal shows Russia is a rotten state (Brenton, 2016).

(70) But we are now living in an age where malign individuals and authoritarian nations such as Russia are able to spray around lies on a global scale, using the firehose power of Facebook and Twitter (The Guardian, 2018).

Making their readers believe that Russia is very dangerous state, British journalists 'visualise' the image of Russia with zoomorphic metaphors comparing it with a strong and dangerous bear as well as with a disgusting octopus:

(71) And Putin's ends are clear. He wants a weak and divided EU. Ultimately, he seeks to break it up, with the Eastern bloc - brought into the European fold by Margaret Thatcher's single market - dragged back into the lair of the Russian bear (Moran, 2019).

(72) [...] the image of the Russian bear is probably preferable to the image of the Russian octopus (Basulto, 2016).

In 1918 a new zoomorphic metaphor, comparing Russia with unpredictable and dangerous gorilla, is used in the British political mass media discourse. This symbolic image shows that Russia is a country with which it is impossible to maintain normal diplomatic relations:

(73) The former British ambassador to Moscow Sir Roderic Lyne counselled against further tit-for-tat diplomatic measures, saying: "It is not sensible to mud-wrestle with $a$ gorilla" (Grierson \& Wintour, 2018).

Emphasizing the danger of Russia, British journalists purposefully use the name of it in micro contexts with such words as aggression, threat, attack, war thus forming the desirable negative associations in interlocutors' minds and convincing them in the necessity to take measures against the aggressive state:

(74) Russia needs to curb its geopolitical aggression (Lynn, 2019). 
N. B. Boeva-Omelechko, et al.

(75) Senior MPs last night called on Downing Street to take urgent action to counter the new Russian threat after The Sun's revelations (Dunn, 2018).

(76) This is the front line of the West's new war with Russia. (Nicholls, 2018).

Military, game and theatrical metaphors used as means of persuasion reinforce the negative associations focusing attention of readers on Russia's aggressive foreign policy. For example:

(77) Theresa May will today offer Russia a path back to warmer relations if it stops its attacks on the West (Coates, 2018).

(78) Russia is mocking us. First the Salisbury attack, then information warfare. Time to wake up [...] Russia is trolling us. This is warfare disguised as political theatre (Cadwalladr, 2018).

Forming the negative image of Russia, British journalists today again form associations of this country with the Empire. In particular, Crimea's accession to Russia is only regarded by British journalists as an attempt to restore the old Empire. For example:

(79) A violent restoration of its old empire (Brzezinski, 2013).

Nowadays British journalists again form associations of Russia with the hated dangerous communist Soviet Union. Many of them consider that Russia has not changed since that time and maybe even became even more dangerous. For example:

(80) Russia maynot have changed that much since the Soviet days (Tisdall, 2014).

Even Skripal poisoning is represented as having some connection with the Soviet past of Russia:

(81) Russia's rise in the poll maybe hard to explain, in a tumultuous year in which Britain accused Moscow of sending two assassins to poison a former Russian intelligence officer with a Soviet-era nerve agent, and a standoff continued between the Kremlin and west over Syria, Ukraine and much else (Durkin, 2019).

No doubt that all means of negative persuasion described above influence greatly the interlocutors' minds evoking different negative feelings against Russia and especially the feeling of fear and insecurity. The negative image of Russia justifies the point of view according to which the best thing the UK can do is

(82)... to stand firm against Russia (Stevens, 2018).

(83) ... to show resolve in the face of alleged Russian aggression (Stevens, 2018).

\section{CONCLUSION}

Treating language as a tool of speech influences modern linguistics lays a special stress on mass media political discourse with its powerful persuasive capacity. The theory of the concept of 'language as dialogue' created by Weigand (see, for instance, 2009, 2010, 2016, 2018) as well as works on mass media discourse by van Dijk $(1981,1989,1993,1995)$ and on new rhetoric by Perelman $(1969,1979)$ provide us with the necessary theoretical assumptions for considering political mass media discourse as a rhetorical argumentative dialogue, in the course of which a journalist convinces interlocutors in a certain point of view, eliciting a particular reaction from them.

The persuasion in this discourse can be subject to ideological tasks thus representing a definite object or phenomenon as positive or negative. It is worth mentioning that one 
and the same object can have opposite assessment in different periods of time. Therefore, the aims of persuasion and linguistic means necessary for them also change.

It is especially true in relation to images of states, which undergo transformations in one and the same discourse due to changes in international relations. According to Boulding (1956), we should distinguish between the favorable 'postwar' periods in which journalists have to convince the recipients of their persuasive messages that a certain state is friendly or at least not dangerous and the rough 'prewar' periods when interlocutors are convinced that the same state is an enemy. It's quite clear that the presupposed reaction of readers as participants of this dialogue and objects of the persuasion will be quite different.

In the effort to convince the audience in their assessment of the state journalists have to use both rational (factual) and emotional or value arguments evoking positive or negative emotions of the audience and thus forming a desirable attitude to the state. The combination of different arguments leads to the formation of the image of state, including its cognitive, affective and evaluative constituents singled out by Boulding (1959).

As factual arguments are beside interests of linguistics, in this paper we focused on revealing and comparing linguistic means used by British journalists for positive persuasion (creation of the positive image of Russia in 1991 - 1993) and negative persuasion (creation of the negative image of Russia in 2013 - 2019).

The first of these periods witnessed the collapse of the Soviet Union, the ideological rival of capitalist states, and the birth of New Russia, presumably less dangerous for Great Britain. At this period, British journalists combined the positive persuasion, aimed at the creation of the positive image of New Russia, with the negative one, oriented towards full and final discreditation of the Soviet Union.

The latter was implemented with the help of nomination Evil Empire, adjectives with negative connotations, depicting the Soviet Union as a tyrannical, cruel and unfriendly system, as well as morbial metaphors representing it as a dead body. British journalists also created micro contexts in which the name of the Soviet Union was used together with such nouns as tyranny, oppression, autocracy, thus forming strong associations between the Soviet Union and all these negative concepts in minds of interlocutors.

Some journalists realized negative persuasion depicting Russia as a successor of the USSR with all its faults and problems. It was persuasion by inertia calling into question the possibility of building a state of a new type on the ruins of the old communist empire. Also the weakness of Russia was opposed to the greatness of the former Empire.

However, for most journalists of that period the negative image of the Soviet Union gave the opportunity to represent an optimistic contrasting image of New Russia born after the collapse of the Evil Empire. They convinced their readers that New Russia is a democratic state with a great potential for development. So British journalists used contrast as another effective way of persuasion, this time a positive one. This contrast was created with the help of such antonymic oppositions as old - new, death (dead, die) - birth (be born), tyranny (oppression) - freedom, autocracy - democracy, poor - prosperous and unfriendly - friendly (friendship). The negative members of these oppositions were used in the contexts, dealing with the Soviet Union, while the positive ones contributed to the creation of the new state. Anthropomorphic metaphors comparing Russia with a newly born baby or a person awakening from the Communist dream and straightening its muscles convinced the readers that Russia has finally understood its misconceptions and is gaining strength. 
N. B. Boeva-Omelechko, et al.

Nowadays the positive persuasion in the British mass media discourse turned into the negative one again. It is aimed at the creation of the image of aggressive Russia, hell-bent on grabbing lands. For purposes of this persuasion British journalists use the technique of manipulating nominations including the word group Hostile State for naming Russia. So British journalists today attract their readers' attention mainly not to inner problems of Russia as it was in 1991 - 1993 but to its foreign policy. Evaluative adjectives with are used by British journalists for depicting modern Russia as an ambitious, authoritarian and dangerous state. They 'visualise' the image of Russia with zoomorphic metaphors comparing it with a strong and dangerous bear as well as with a disgusting octopus or unpredictable gorilla. British journalists purposefully use the name of Russia in micro contexts with such words as aggression, threat, attack, war thus forming the desirable negative associations and convincing readers in the necessity to take measures against the aggressive state. Military, game and theatrical metaphors reinforce the negative associations focusing attention of readers on Russia's aggressive foreign policy.

The paper contributes to the problems of dialogical character of political mass media discourse and linguistic means of persuasion aimed at the creation and transformation of images of states. It can be useful for linguists, rhetoricians and journalists.

\section{ACKNOWLEDGEMENT}

The publication has been prepared with the support of the Southern Federal University.

The publication has been prepared with the support of the "RUDN University Program $5-100 "$

\section{REFERENCES}

Austin, J. L. (1962). How to Do Things with Words. The William James Lectures. Delivered at Harvard University in 1955. London: Oxford University Press.

Basulto, D. (2016, July 10). Russophobia and the Dark Art of Making an Anti-Russian Magazine Cover. Retrieved from www.medium.com

Bayers, R. (1992, January 3). Yeltsin Applies Shock Therapy to Revive Mother Russia. The Times, № 64219.

Beaumont, P. (2018, September 11). Russia's Scramble for Influence in Africa Catches Western Officials Off-guard. The Guardian. Retrieved from https://www.theguardian .com/global-development/2018/sep/11/russias-scramble-for-influence-in-africa-catche s-western-officials-off-guard

Bierwisch, M. (1971). Modern Linguistics. Its Development, Methods and Problems. Paris: Mouton.

Binton, M. (1992, January 17). The City Helps Russia Get Out of the Red. The Times, № $64231,11$.

Boeva-Omelechko, N. B. (2001). Grammaticheskaya Antonimiya $V$ Sovremennom Angliyskom Yazyke (PhD Thesis). Moscow: Moscow State Pedagogical University.

Boeva-Omelechko, N. B., Zheltukhina, M. R., Ryabko, O. P., Matveeva, G. G., Murugova, E. V., \& Zyubina, I. A. (2018). Unusual Antonyms: Inter-Part-Of-Speech Interaction in English Fictional Discourse. Space and Culture, India, 6(4), 112-121. https://doi.org/10.20896/saci.v6i4.387

Bolton, L. (1991, August 19). Yeltsin Plays On. The Financial Times. № 31534, 2.

Boulding, K. E. (1956). The Image: Knowledge in Life and Society. Ann Arbor: The University of Michigan Press. https://doi.org/10.3998/mpub.6607 
Online Journal of Communication and Media Technologies, 2019

Boulding, K. E. (1959). National Images and International Systems. The Journal of Conflict Resolution, 3(2), 120-131. https://doi.org/10.1177/002200275900300204

Brenton, T. (2016, July 24). The Doping Scandal Shows Russia Is a Rotten State - But We Must Not Seek a Pointless Confrontation. The Daily Telegraph.

Brinker, K. (1997). Linguistische Textanalyse. Eine Einfuehrung in Grundbegriffe und Methoden. Berlin: Erich Schmidt.

Brzezinski, Z. (2013, December 10). Russia, Like Ukraine, Will Become a Real Democracy. The Financial Times. № 38432, 14.

Cadwalladr, C. (2018, September 15). Russia is Mocking Us. First the Salisbury Attack, Then Information Warfare. Time to Wake Up. The Guardian. Retrieved from https:/www.theguardian.com/commentisfree/2018/sep/1-5/russia-is-mocking-us-

first-the-salisbury-attack-then-information-warfare-time-to-act

Coates, S. (2018, November 20). Russia Offered Thaw in Relations If It Stops Attacks on West. The Times. Retrieved from https://www.thetimes.co.uk/article/russia-offeredthaw-in-relations-if-it-stops-attacks-on-west-f6dcxjgkl

Crystal, D. (2008). A Dictionary of Linguistics and Phonetics. Oxford: Blackwell Publishing. https://doi.org/10.1002/9781444302776

Davies, N. (1991, August 22). Democracy or the Soviet Union - But Not Both. The Daily Telegraph. № 42351, 16.

Dejevsky, M. (1991, December 23). The SU Is No More. The Times. № 64210, 12.

Dunn, T. N. (2018, October 8). Russia Sends Troops and Missiles into Libya in Bid to Enforce Stranglehold on the West. In: The Sun. Retrieved from https://www.thesun.co.uk/news/7448072/russia-missiles-libya-warlord

Durkin, E. (2019, February 28). US in Virtual Tie with Russia on Global Confidence, Poll Finds. The Guardian. Retrieved from https://www.theguardian.com/usnews/2019/feb/28/global-confidence-us-russia-gallup-poll-report-tie

Fallon, M. (2017, February 2). Coping with Russia. Retrieved from https://www.gov.uk/government/speeches/coping-with-russia

Finnegan, E. G. 1989. New Webster' Dictionary of the English Language. Delhi: Surjeet Publications.

Firth, J. R. (1957). Papers on Linguistic. Oxford: Oxford University Press.

Fishlock, T. (1991, August 20). Brezhnev's Ghostly Sniggers Echo Bloody Walls of the Kremlin. The Daily Telegraph. № 42349, 2.

Frankland, M. (1991a, January 13). The Captain Gets Lost in a Russian Fog. The Observer. № 10396, 17.

Frankland, M. (1991b, December 22). Lonely Victim of Imperial Delusions. The Observer. № 10445,16 .

Frankland, M. (1992a, April 12). Yeltsin Wants Russians to Be More Revolving. The Observer. № 10461, 2.

Frankland, M. (1992b, December 15). The Fault Is in Yeltsin Not in His Enemies. The Observer. № 10497, 3.

Grierson, J., \& Wintour, P. (2018, March 17). Sergei Skripal: Russia Expels 23 UK Diplomats as Row Deepens. The Guardian. Retrieved from https://www.theguardian. com/world/2018/mar/17/sergei-skripal-russia-expels-23-british-diplomats

Gumperz, J. J. (1982). Discourse Strategies. Cambridge: Cambridge University Press. https://doi.org/10.1017/CBO9780511611834

Harris, Z. S. (1952). Discourse Analysis. Language, 28(1), 1-30. https://doi.org/10.2307/409987 
N. B. Boeva-Omelechko, et al.

Hastings, M. (1991a, August 27). A Dangerous Ruin. The Daily Telegraph. № 42356, 12.

Hastings, M. (1991b, August 22). The End of Communism - By Order of the People. The Daily Telegraph. № 42351, 16.

Hastings, M. (1991c, August 21). The West for Yeltsin. The Daily Telegraph. № 42350, 14. Hastings, M. (1992, January 14). Faith in the Russians. The Daily Telegraph. № 42463, 14.

Hastings, M. (2017, January 18). Without America Britain Must Lead Standing Tsar Putin New Imperial. The Daily Telegraph. Retrieved from https://www.telegraph.co. uk/news/2017/01/18/without-america-britain-must-lead-standing-tsar-putins-newimperial/

Hundsnurscher, F. (1992). Does a Dialogic View of Language Amount to a Paradigm Change in Linguistics: Language As Dialogue. Tuebingen: Niemeyer. https://doi.org/10.1515/9783111332024-002

Jenkins, S. (1991, August 19). Yeltsin's Heroic Day. The Times. № 64082, 1.

Johnson, B. (2018, February 22). Four Years since the Illegal Annexation of Crimea. Retrieved from https:/www.gov.uk/government/speeches/four-years-since-theillegal-annexation-of-crimea-article-by-boris-johnson

June, S. T. (2016, June 23). The Trap of "Countering Russia". Retrieved from https://www.opendemocracy.net/en/odr/trap-of-countering-russia

Kariakina, A. (2019, March 6). Five Years on from 'Maidan', Ukraine's Small Successes are Its Real Revolution. The Guardian. Retrieved from https://www.theguardian. com/commentisfree/2019/mar/06/five-years-ukraine-maidan-revolution-2014

Koppersmith, E. (1973). Allgemeine Rhetorik, Einfuehrung in die Theorie der persuasiven Kommunikation. Stuttgart: W. Kohlhammer.

Kortunov, A., \& Chalmers, M. (2018, April 17). Like It or Not, Russia and The UK Need Each Other - And Will Have to Talk. The Guardian. Retrieved from https://www.theguardian.com/commentisfree/2018/apr/17/ru-ssia-uk-skripal-syria

Lakoff, G. N., \& Johnsen, M. (2003). Metaphors We Live By. Chicago: The University of Chicago Press. https://doi.org/10.7208/chicago/9780226470993.001.0001

Lakoff, R. (1982). Persuasive Discourse and Ordinary Conversation, with Examples from Advertising. In: D. Tannen (Ed.), Analyzing Discourse: Text and Talk (pp. 25-42). Washington DC: Georgetown University Press.

Lambert, R. (1991, June 12). The Importance of Mr. Yeltsin. In: The Financial Times. № 10464, 1.

Lawson, D. (1992, April 16). Our White Knight Meets a Russian King. In: The Observer. 3.

Leech, G. N. (1983). Principles of Pragmatics. London: Longman.

Levinson, S. C. (1983). Pragmatics. Cambridge: CUP. XVI. https://doi.org/10.1017/CBO9 780511813313

Lloyd, J. (1991, August 22). Fading of the Grey Man’s Fantasy. The Financial Times. № $31537,2$.

Lloyd, J. (1993a, October 5). Victory for All the President's Men. The Financial Times. № $32183,1$.

Lloyd, J. (1993b, August 31). After a Long Sleep, Russia Awakes. The Financial Times. № 31554,6 .

Lloyd, J., \& Freeland, C. (1993, January 1). Fear of Sharing a Bed with the 'Russian Elephant'. The Financial Times. № 31976, 2. 
Online Journal of Communication and Media Technologies, 2019

Lynn, M. (2019, March 4). Free Trade Revolution in Brazil, Russia and China: This Could Be the Year Emerging Markets Take Off. The Daily Telegraph.

May, T. (2018, March 14). A Statement to the House of Commons by Prime Minister Theresa May Following the Salisbury Incident. Retrieved from https://www.gov.uk/ government/speeches/pm-commons-statement-on-salisbury-incident-response-14march-2018

Mcelvoy, A. (1993, December 29). Is Tyranny Rooted in Russian Psyche? The Times. 12.

Mendras, M. (2018, July 25). Vladimir Putin's Russia Is a Creaking Ship. Don't Fall for the Propaganda. The Guardian. Retrieved from https://www.theguardian.com/ commentisfree/2018/jul/25/propaganda-putin-russia-elections

Millinship, W. (1991a, July 14). Welcome to the Man with Gifts from Moscow. The Observer. № 10423, 18.

Millinship, W. (1991b, December 8). What's Left for Gorbachev. The Observer. № 10443, 10.

Minakova, N. A., Ponomarenko E. B., \& Talibina E. V. (2018). About three groups of loanwords of mass media language (on the material of Moscow newspapers). Scientific and practical journal. Modern science: actual problems of theory and practice, The Humanities series. M., OOO KOPI-PRINT, (4), 139-143.

Moran, L. (2019, January 10). I Asked Theresa May If She Sides with Putin or the People And Tell Us If Brexit Is Real. The Independent. Retrieved from https://www.independent.co.uk/voices/brexit-theresa-May-vladimir-putin-secondreferendum-leave-eu-boris-johnson-a8721011.html

Mujanović, J. (2014). Moscow's Man in Banja Luka. Retrieved from https://www.opendemocracy.net/en/odr/moscows-man-in-banja-luka/

Nicholls, D. (2018, September 20). Gavin Williamson Commits Extra British Troops in Ukraine to Stop Russia 'Reversing Cold War Outcome. The Telegraph. Retrieved from https://www.telegraph.co.uk/news/2018/09/20/gavin-williamson-commits-extra-

british-troops-ukraine-stop-russia/

NougayrèdE, N. (2019, March 1). Assad Can Still Be Brought to Justice - And Europe's Role Is Crucial. The Guardian. Retrieved from https://www.theguardian.com/ commentisfree/2019/mar/01/assad-europe-lawyers-syrian-war-criminals

Parker, I. (1999). Introduction: Varieties of Discourse and Analysis. In: I. Parker (Ed.) Critical Textwork: an Introduction to Varieties of Discourse and Analysis, Bolton Discourse Network, Buckingham: Open University Press, pp. 1-12.

Perelman, C. (1979). The New Rhetoric: A Theory of Practical Reasoning. Chaim Perelman, with an introduction by Harold Zyskind. The New Rhetoric and the Humanities. Essays on Rhetoric and Its Application. London: D. Riedel Publishing Company. https://doi.org/10.1007/978-94-009-9482-9_1

Perelman, C., \& Olbrechts-Tyteca, L. (1969). The New Rhetoric. A Treatise on Argumentation. Indiana: University of Notre Dame Press.

Pipes, R. (1991, August 24/25). The End of 1917. The Financial Times. № 31539, 23.

Ponsett, R. (1991, June 17). Two Sides of Case for Coexistence. The Times. № 64044, 14.

Posternyak, K. P., \& Boeva-Omelechko, N. B. (2018). The formation of the image of Russia in the British political mass media discourse. Acta Scientiarum. Language and Culture, 40(2), e41086. https://doi.org/10.4025/actascilangcult.v40i2.41086

Pragglejaz Group. (2007). MIP: a Method for Identifying Metaphorically Used Words in Discourse. Metaphor and Symbol, 22(1), 1-39. https://doi.org/10.1080/ 10926480709336752 
N. B. Boeva-Omelechko, et al.

Preston, P. (1992, December 11). Yeltsin Asks the People to Decide. The Guardian. № 45489, 13.

Preston, P. (1993a, March 22). A Coup In the Name Of Freedom. The Guardian. 3.

Preston, P. (1993b, October 5). Can the Tanks Bring Freedom? In: The Guardian. 3.

Preston, P. (1993c, January 1). No Turning Back In Russia. The Guardian. 14.

Privalova, I. V., Shaidullina, A. R., Zheltukhina, M. R., Grinberg, T. E., \& Garcia Caselles, C. (2019). Coerced loss of national colorings - linguistic issues of virtual team communication. XLinguae, 12(1), 151-164. https://doi.org/10.18355/XL.2019.12.01.12

Rachman, G. (2018, March 19). Vladimir Putin is not as scary as he looks. The FT. Retrieved from https://www.ft.com/content/c9d6f278-2931-11e8-b27e-cc62a39d57a0

Repina, E. A., Zheltukhina, M. R., Kovaleva, N. A., Popova, T. G., \& Garcia Caselles, C. (2018). International media image of Russia: trends and patterns of perception. XLinguae, 11(2), 557-565. https://doi.org/10.18355/XL.2018.11.02.45

Searle, J. R. (1969). Speech Acts. An Essay in the Philosophy of Language, Cambridge: Cambridge University Press.

Searle, J. R. (1983). Intentionality. An Essay in the Philosophy of Mind. Cambridge: Cambridge University Press. https://doi.org/10.1017/CBO9781139173438

Stevens, T. (2018, October 5). At a Time of Permanent Cyberwar, the UK Must Stand Firm against Russia. The Guardian. https://doi.org/10.1017/CBO9781139173452

Stothard, P. (1993, May 5). October Dawn. The Times. № 64766, 19.

Tameryan, T. Yu., Zheltukhina, M. R., Sidorova, I. G., \& Shishkina, E. V. (2019). Stereotype Component in the Structure of Ethnocultural Archetype (On InternetBlogs). The European Proceedings of Social \& Behavioural Sciences, 200, 1716-1722. https://doi.org/10.15405/epsbs.2019.03.02.200

Tameryan, T. Yu., Zheltukhina, M. R., Slyshkin, G. G., Abakumova, O. B., Volskaya, N. N., \& Nikolaeva, A. V. (2018a). Metaphor in Political Media Discourse: Mental Political Leader Portrait. Online Journal of Communication and Media Technologies, 8(4), 377-384. https://doi.org/10.12973/ojemt/3958

Tameryan, T. Yu., Zheltukhina, M. R., Slyshkin, G. G., Shevchenko, A. V., Katermina, V. V., \& Sausheva, Ye. V. (2018b). New Country's Political Discourse: Formation of Speech Technologies. Modern Journal of Language Teaching Methods, 8(7), 151-160.

Thomas, J. A. (19950. Meaning in Interaction. An Introduction to Pragmatics. London: Longman.

Till, P. (1992, October 10). Russian Medicine That Turned Sour. In: The Guardian. 5.

Tisdall, S. (2014, November 19). The New Cold War: Are We Going Back to the Bad Old Days? The Guardian.

Traynor, I. (1993, March 23). Constitutional Right on Side of Congress. The Guardian.

Trenin, D. (2017, March 27). Russia Is the House That Vladimir Putin Built -Abandon It. And He'll Never Abandon. The Guardian.

Van Dijk, T. A. (1981). Studies in the Pragmatics of Discourse. Hague: Mouton. https://doi.org/10.1515/9783110826142

Van Dijk, T. A. (1989). Structures of Discourse and Structures of Power (pp. 18-59). Newbury Park: Sage Publications. https://doi.org/10.1007/978-1-137-07299-3_2

Van Dijk, T. A. (1993). Principles of Critical Discourse Analysis. Discourse and Society, 4(2), 249-283. https://doi.org/10.1177/0957926593004002006

Van Dijk, T. A. (1995). Aims of Critical Discourse Analysis. Japanese Discourse, 1(1), 17 27. https://doi.org/10.1177/0957926594005004001 
Online Journal of Communication and Media Technologies, 2019

Viner, K. (2018, July 15). The Guardian View on the Trump-Putin Meeting: Good for Vladimir, But Not for the Rest of Us. The Guardian. Retrieved from https://www.theguardian.com/commentisfree/2018/jul/15/the-guardian-view-on-thetrump-putin-meeting-good-for-vladimir-but-not-for-the-rest-of-us

Volskaya, N. N., Tameryan, T. Yu., Zheltukhina, M. R., Boeva-Omelechko, N. B., Komleva, L. A., \& Knyazeva, Ye. G. (2018). Literary Translation as Cognitive Overlap between Foreign and Native Languages. Modern Journal of Language Teaching Methods, 8(7), 161-172.

Warren, M. (1991, October 24). A Merry Dance of Revolution. The Daily Telegraph. № 42353, 1.

Weaver, M. (1991, August 21). So, What Will Happen Next? The Daily Telegraph. № 42350, 15.

Weigand, E. (2009). Language as Dialogue. From Rules to Principles of Probability. Amsterdam: Benjamins. https://doi.org/10.1075/ds.5

Weigand, E. (2010). Dialogue: The Mixed Game. Philadelphia: Benjamins. https://doi.org/10.1075/ds.10

Weigand, E. (2015). Dialogue in the Stream of Life. In: Language and Dialogue, 5(2), 197 223. https://doi.org/10.1075/ld.5.2.01wei

Weigand, E. (2016). How to Verify a Theory of Dialogue. Language and Dialogue, 6, 349369. https://doi.org/10.1075/ld.6.3.01wei

Weigand, E. (2017). Iada History. The Unity of the Dialogue and its Multiple Faces. Language and Dialogue, 7(1), 63-79. https://doi.org/10.1075/ld.7.1.05wei

Weigand, E. (2018). Dialogue: The Key to Pragmatics. From Pragmatics to Dialogue. Philadelphia: Benjamins. https://doi.org/10.1075/ds.31

While, D. (1991, August 28). Russia Likely to Become New Nuclear Superpower. In: The Financial Times. № 315541. 2.

Zheltukhina, M. R., Bondareva, N. V., Zelenskaya, L. L., Anikeeva, I. G., Malygina, L. E. \& Chistyakov, A. V. (2019). Media Promotion Role of Economic Vocabulary: Specific Features and Functions in Presentation and Advertisement. Online Journal of Communication and Media Technologies, 9(2), e201907. https://doi.org/10.29333/ojemt/5733

Zheltukhina, M. R., Krasavsky, N. A., Ponomarenko, E. B., Aleshchanova, I. V., \& Pavlov, P. V. (2016a). Political Facebook Posts Using Ideological Symbols for Media Image Designing of Russia as Enemy. International Journal of Environmental and Science Education, 11(18), 12005-12013.

Zheltukhina, M. R., Slyshkin, G. G., Ponomarenko, E. B., Busygina, M. V., \& Omelchenko, A. V. (2016b). Role of Media Rumors in the Modern Society. International Journal of Environmental and Science Education, 11(17), 10581-10589.

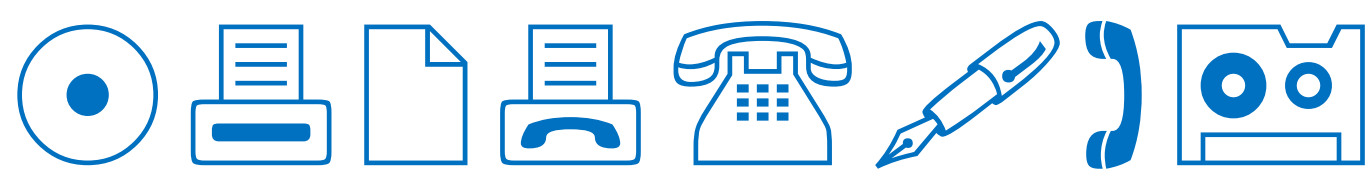

